\title{
Behavioural Study of Market Arrivals and Prices of Tomato in Major Markets of Tamil Nadu - A Time Series Analysis
}

\author{
C. Tamilselvi, G. Mohan Naidu*, B. Ramana Murthy and S. Rajeswari \\ Department of Statistics \& Computer Applications, S.V. Agricultural College, \\ Tirupati (A.P), India \\ *Corresponding author
}

\section{A B S T R A C T}

This study has been undertaken with the twin objectives of examining the variability pattern of market arrivals (Qtls) and prices (Rs/qtl) of tomato in

\section{Keywords}

Tomato, Secular Trend, Seasonal Indices, ANOVA, Correlation

Article Info

Accepted:

22 June 2020

Available Online:

10 July 2020 three major markets of Tamil Nadu viz., Ottanchatram Gandhi market, Madurai Paravai market and Coimbatore wholesale market and analysing the relationship between market arrivals and prices. The study is based on market arrivals and wholesale prices of tomato were collected from the respective agricultural marketing committees for the period 2011-2018. Arrivals of tomato showed a decreasing trend in Oddanchatram and Paravai markets whereas an increasing trend in Coimbatore vegetable market. In prices, there was a mixed trend in all the markets. Peak arrivals observed during the month of March and lowest in August whereas maximum price observed in July and lowest in February in Oddanchatram market; maximum arrivals in November and minimum in August while highest price in November and lowest in February in Paravai market; peak arrivals observed in December and lean in June whereas maximum prices were

\section{Introduction}

Tomato (Lycopersicon esculentum) popularly known as 'protective foods' because it naturally bestows with numerous minerals and vitamin like vitamin C, vitamin K1, folate and potassium. One of the largest cultivating vegetable crops next to potato is tomato and also tops in canned vegetables. According to third advance estimates of 2018-19, India has
778 thousand hectares of tomato cultivation and its production is estimated to be 19397 thousand MT (source: Ministry of Agriculture and Farmers Welfare).

In Tamil Nadu, it covers an area of 29 thousand hectares and the major growing pockets are Salem, Krishnagiri, Vellore, Dharmapuri, Trichy, Coimbatore and Dindigul district. The most preferable season 
is Thai pattam (January - February) but it grows mostly in all season. The predominant varieties in Tamil Nadu are PKM 1, Marutham, Paiyur 1 and COTH 2. The major constraints in tomato cultivation are unseasonal rainfall, heat stress, hot weather and meager germination of seeds that leads to a price ascend.

In these days, arrivals and prices of horticulture produces are showing high volatility. The prices volatilization has a catastrophic effect on all the group of farmers involving consumption, production and marketing of the commodities. In the age of trade liberalization, the prevalence of the problem of high fluctuation in arrivals and prices in domestic as well as international markets has gain significance importance. The prices in a market are determined not only by the interplay of supply along with demand but also by socio-economic factors existing in that region. So, a detailed examination of region/state wise is substantial to comprehend the behaviour of arrival and prices in a market.

\section{Materials and Methods}

The secondary data regarding monthly arrivals and prices of tomato for a period of 8 years (2011-2018) were collected from respective market management committees of Ottanchatram Gandhi market, Madurai Paravai market and Coimbatore wholesale market.

For analysis of time series data, a model is essential. Generally two broad approaches are resorted too. One is a multiplicative model and the other is an additive model. There could be other approaches too resulting in a hybrid model of these two. In this present study multiplicative model has been employed, since many of agricultural data admit such a model as a more appropriate one. The behaviour of market arrivals and prices have been studied by Baby Dey et al.,(2014); Bera et al., 2017); Kumuda Keerthi and Mohan Naidu (2013); Mhatre et al., (2018); Mohan Naidu and Ravindra Reddy (2013) and Preethi et al., (2019).

Let the original observation at the time point to be denoted by $\mathrm{Y}_{\mathrm{t}}$ and the four components viz., Trend, seasonal, Cyclical and Irregular Variations by $\left(\mathrm{T}_{\mathrm{t}}\right), \quad\left(\mathrm{S}_{\mathrm{t}}\right), \quad\left(\mathrm{C}_{\mathrm{t}}\right)$ and $\left(\mathrm{I}_{\mathrm{t}}\right)$ respectively for a time period $\mathrm{t}$ (where $\mathrm{t}=1$, $2,3, \ldots)$. Then the multiplicative model can be expressed as

$Y_{t}=T_{t} * S_{t} * C_{t} * I_{t}$

Where,

$Y_{t}=$ Observed value of the time series in time period $\mathrm{t}$

$\mathrm{T}_{\mathrm{t}}=$ Trend component at time period $\mathrm{t}$

$\mathrm{S}_{\mathrm{t}}=$ Seasonal component at time period $\mathrm{t}$

$\mathrm{C}_{\mathrm{t}}=$ Cyclical component at time period $\mathrm{t}$

$\mathrm{I}_{\mathrm{t}}=$ Irregular component at time period $\mathrm{t}$

\section{Analysis of long-term movements (Trend)}

The residuals $\left(\boldsymbol{T}_{t}=\frac{\boldsymbol{Y}_{t}}{S_{t} \times C_{t}}\right)$ after eliminating seasonal effects and cyclical effects (if any) from original observations $\left(\mathrm{Y}_{\mathrm{t}}\right)$ are used to determine the trend. If there is no cyclical pattern, then trend cycle components are treated as trend values. When definite mathematical model cannot be identified to fit trend data, the orthogonal polynomials are used to determine the long term behavior. These polynomials are fitted by the method of least squares.

Polynomial Equation:

$Y_{t}=b_{0}+b_{1} t+b_{2} t^{2}+\ldots \ldots .+b_{n-1} t^{n-1}+b_{n} t^{n}$ 
Where,

$Y_{t}=$ Trend values of at time ' $\mathrm{t}$ '

$t=$ time period and

$b_{0}, b_{1}, b_{2}, \ldots \ldots, b_{n-1}, b_{n}$ are the coefficient to be estimated.

The suitable model for data is judged based on Adjusted $\mathrm{R}^{2}$ value. Annual trends of prices and arrivals for the selected markets were computed and compared. The goodness of fit of trend line to the data was tested by the coefficient of multiple determination which is denoted by $\mathrm{R}^{2}$.

\section{Estimation of seasonal indices of monthly data}

The multiplicative model permits the estimation of each of the above four components. As a first step to estimate the seasonal index a 12-month moving averages was calculated as follows:

$$
\begin{aligned}
& M_{1}=\frac{Y_{1}+Y_{2}+Y_{3}+\ldots \ldots .+Y_{12}}{12} \\
& M_{2}=\frac{Y_{2}+Y_{3}+Y_{4}+\ldots \ldots .+Y_{13}}{12} \\
& M_{3}=\frac{Y_{3}+Y_{4}+Y_{5}+\ldots \ldots .+Y_{14}}{12} \ldots . \text { etc. },
\end{aligned}
$$

This is a sequential manner for each points of time $\mathrm{t}$.

In this fashion a 12 month centered moving average removes a large part of fluctuation due to seasonal effects so that what remains is mainly attributable to other sources viz., longterm effects $\left(T_{t}\right)$ and cyclical effect $\left(C_{t}\right)$ the irregular variation $\left(\mathrm{I}_{\mathrm{t}}\right)$ due to random causes is also minimized as process of smoothing out effect. Thus, this affords a means of not only estimating trend cycle effect but also estimating seasonal components.

In the next step of computing the seasonal index, the original series is divided by the cantered moving average. This gives the first estimate of seasonal components $\left(\mathrm{S}_{\mathrm{t}}\right)$.

$S_{t}=\frac{Y_{t}}{(T C)_{t}}=\frac{T_{t} C_{t} S_{t} I_{t}}{T_{t} C_{t}}$

It is always expressed in terms of percentages. In this process, we do not have moving average for first six and last six months. For evaluation of seasonality in arrivals and prices of tomato, the multiplicative time series, twelve month centered moving average, twoway ANOVA were used.

\section{Correlation analysis}

Correlation co-efficient is obtained to measure the nature and magnitude of relationship between arrivals and prices of selected commodities of the market. The coefficient of correlation " $\mathrm{r}$ " was calculated using the formula

$$
\mathrm{r}=\frac{\left.\frac{1}{n} \sum_{i=1}^{n}\left(x_{i}-\bar{x}\right)\left(y_{i}-\bar{y}\right)\right)}{\sqrt{\frac{1}{n} \sum_{i=1}^{n}\left(x_{i}-\bar{x}\right)^{2}} \sqrt{\frac{1}{n} \sum_{i=1}^{n}\left(y_{i}-\bar{y}\right)^{2}}}
$$

Test for significance of correlation coefficient

$\mathrm{t}=\frac{|r|}{\sqrt{1-r^{2}}} \sqrt{n-2}$

which follows Student's $\mathrm{t}$ - distribution with ( $\mathrm{n}-2$ ) degrees of freedom.

\section{Results and Discussion}

The trend in arrivals and prices of tomato can be analysed by fitting the respective 
polynomial. The fitted equation along with adjusted $\mathrm{R}^{2}$ for tomato arrivals and prices are given in the Tables $1 \& 2$ respectively.

In order to analyze the nature of trend in arrivals of tomato, the data was adequately fitted the first degree equation in Oddanchatram and Coimbatore market but in case of Paravai market, it was computed by fitting third degree polynomial. The average monthly arrivals of tomato in Oddanchatram market would be 27777 quintals and the average arrivals were decreased by 34 quintals. The average monthly arrivals of tomato in Coimbatore vegetable market would be 3883 quintals and the average arrivals were increase by 15 quintals. The trend in prices was analyzed by fitting third degree polynomial in all three markets. The trend in arrivals and prices of tomato in selected markets were depicted in Figures 1 to 6 respectively.

It can be observed from Figures 1 to 6 that arrivals of tomato displayed a decreasing trend over the years in Oddanchatram and
Paravai markets but it showed an increasing trend in Coimbatore vegetable market. Prices of tomato displayed a mixed trend in all three markets.

\section{Seasonal indices}

Being a highly perishable commodity, tomato is extremely susceptible to price variations in the market implying that the produce should be immediately sold and cleared from the market without and delay. This means that prices in highly dependent on the current supply and demand. Supply and demand can change in a matter of days, thus making tomato prices quite volatile. It is proposed to examine the seasonality in arrivals and prices over time to quantify the observable variation.

Seasonal Indices were calculated for each month in order to understand the pattern of variation within a year in the tomato arrivals and prices. The final estimated Seasonal Indices for arrivals and prices of tomato in selected markets are given in Table 3.

Table.1 Secular trend analysis for monthly arrivals of tomato in selected markets

\begin{tabular}{|c|c|c|}
\hline Market & Fitted Equation & Adjusted $\mathbf{R}^{2}$ \\
\hline Oddanchatram & $\mathrm{Y}_{\mathrm{t}}=27777-34.16 \mathrm{t}$ & 0.0023 \\
\hline Paravai & $\mathrm{Y}_{\mathrm{t}}=63962-45.92 \mathrm{t}+2.138 \mathrm{t}^{2}-0.021 \mathrm{t}^{3}$ & 0.0511 \\
\hline Coimbatore & $\mathrm{Y}_{\mathrm{t}}=3883+15.73 \mathrm{t}$ & 0.0781 \\
\hline
\end{tabular}

Table 2: Secular trend analysis for monthly prices of tomato in selected markets

\begin{tabular}{|c|c|c|}
\hline Market & Fitted Equation & Adjusted $\mathbf{R}^{2}$ \\
\hline Oddanchatram & $\mathrm{Y}_{\mathrm{t}}=1303-16.80 \mathrm{t}+1.330 \mathrm{t}^{2}-0.012 \mathrm{t}^{3}$ & 0.1055 \\
\hline Paravai & $\mathrm{Y}_{\mathrm{t}}=1394-4.709 \mathrm{t}+0.778 \mathrm{t}^{2}-0.007 \mathrm{t}^{3}$ & 0.5097 \\
\hline Coimbatore & $\mathrm{Y}_{\mathrm{t}}=1372-35.47 \mathrm{t}+1.625 \mathrm{t}^{2}-0.013 \mathrm{t}^{3}$ & 0.0800 \\
\hline
\end{tabular}


Table.3 Estimated seasonal indices for arrivals and prices of tomato in selected markets

\begin{tabular}{|c|c|c|c|c|c|c|}
\hline & \multicolumn{2}{|c|}{ Oddanchatram market } & \multicolumn{2}{|c|}{ Paravai market } & \multicolumn{2}{c|}{ Coimbatore market } \\
\hline Months & Arrivals & Prices & Arrivals & Prices & Arrivals & Prices \\
\hline January & 118.38 & 79.96 & 103.2 & 66.9 & 102.63 & 76.42 \\
\hline February & 101.45 & $\mathbf{5 0 . 0 7}$ & 94.78 & $\mathbf{5 6 . 7 3}$ & 98.27 & $\mathbf{4 5 . 4 4}$ \\
\hline March & $\mathbf{1 2 7 . 8 1}$ & 51.49 & 94.37 & 59.96 & 112.89 & 50.27 \\
\hline April & 123.25 & 91.78 & 86.06 & 84.32 & 92.63 & 89.73 \\
\hline May & 125.52 & 129.77 & 100.71 & 120.34 & 86.94 & 142.53 \\
\hline June & 98.78 & 163.80 & 124.19 & 110.42 & $\mathbf{8 4 . 9 1}$ & $\mathbf{1 7 8 . 4 6}$ \\
\hline July & 78.62 & $\mathbf{1 6 5 . 7 2}$ & 83.32 & 132.26 & 96.14 & 167.78 \\
\hline August & $\mathbf{7 2 . 4 4}$ & 106.82 & $\mathbf{7 8 . 5 8}$ & 88.42 & 99.26 & 98.94 \\
\hline September & 91.33 & 67.70 & 108.17 & 77.09 & 100.23 & 65.39 \\
\hline October & 92.38 & 79.84 & 97.14 & 110.41 & 92.18 & 82.09 \\
\hline November & 78.53 & 118.09 & $\mathbf{1 3 2 . 6 9}$ & $\mathbf{1 9 3 . 9 3}$ & 109.57 & 114.31 \\
\hline December & 91.51 & 94.96 & 96.79 & 99.21 & $\mathbf{1 2 4 . 3 5}$ & 88.65 \\
\hline
\end{tabular}

Table.4 Correlation coefficients for arrivals and prices of tomato in the selected markets

\begin{tabular}{|c|c|c|c|}
\hline Markets & r & 't' Value & p Value \\
\hline Oddanchatram & -0.1641 & 1.6133 & 0.1100 \\
\hline Paravai & 0.3138 & 3.2046 & $0.0018^{* *}$ \\
\hline Coimbatore & -0.2024 & 2.0042 & $0.0479^{*}$ \\
\hline
\end{tabular}

*Significant at $5 \%$ level of significance, ** Significant at $1 \%$ level of significance

Figure.1 Secular trend analysis of monthly arrivals of tomato in Oddanchatram market

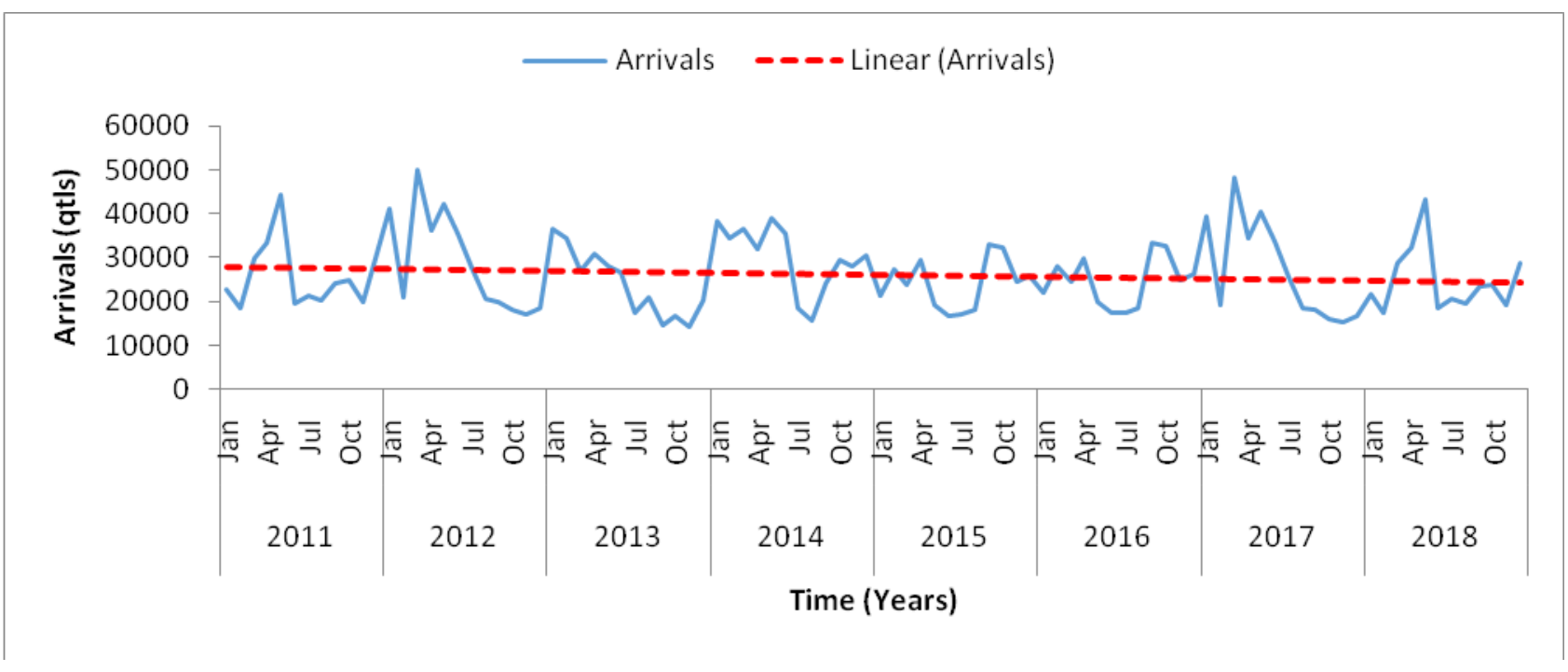


Figure.2 Secular trend analysis of monthly arrivals of tomato in Paravai market

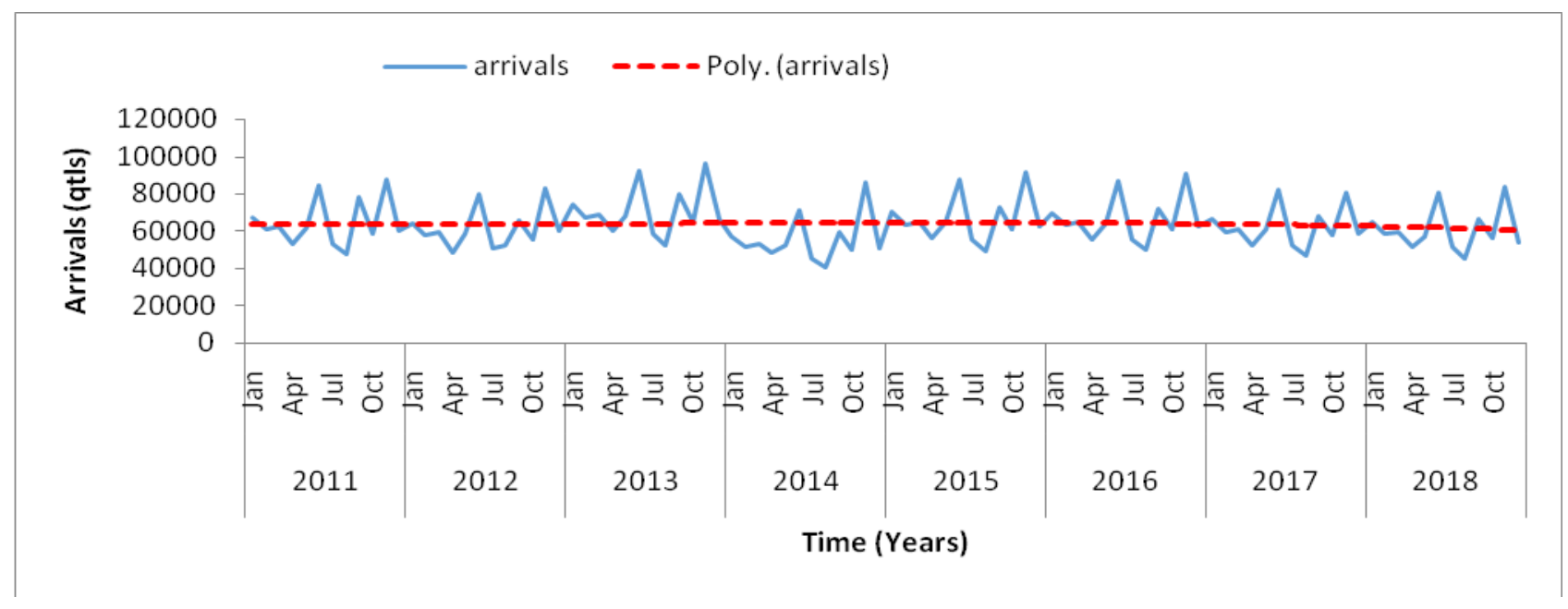

Figure.3 Secular trend analysis of monthly arrivals of tomato in Coimbatore market

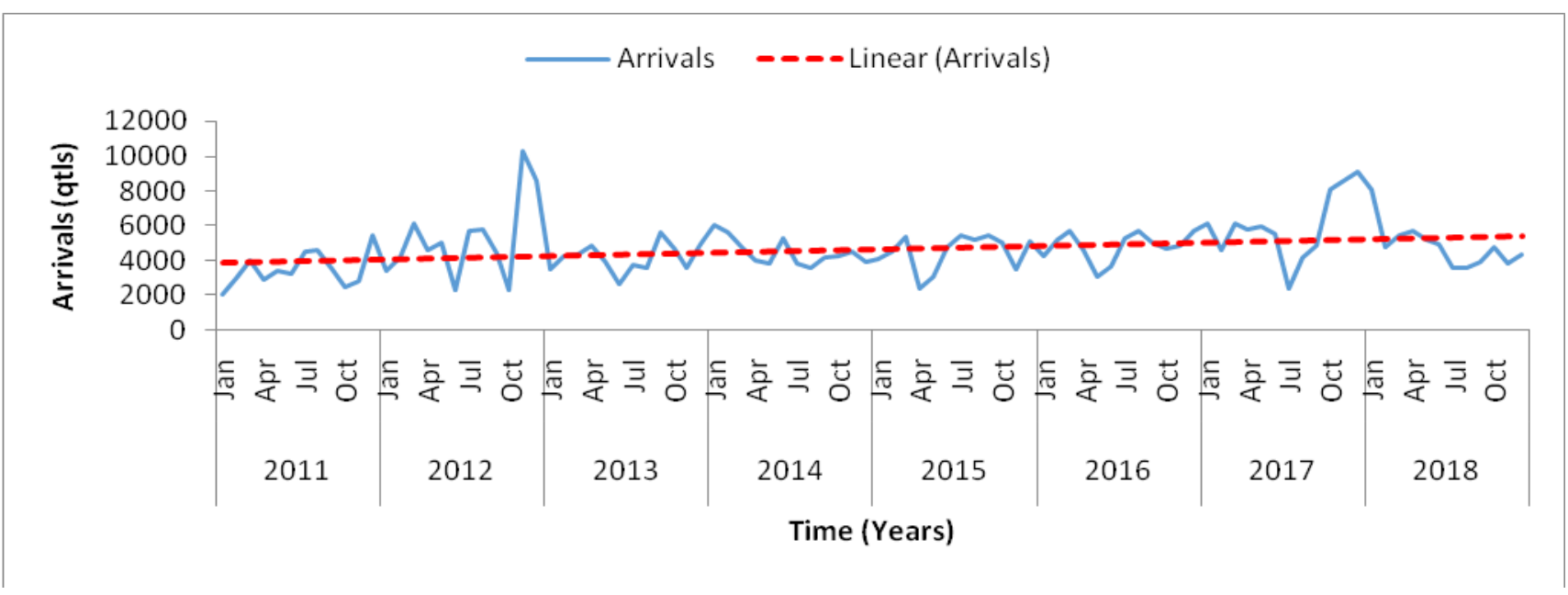

Figure.4 Secular trend analysis of monthly prices of tomato in Oddanchatram market

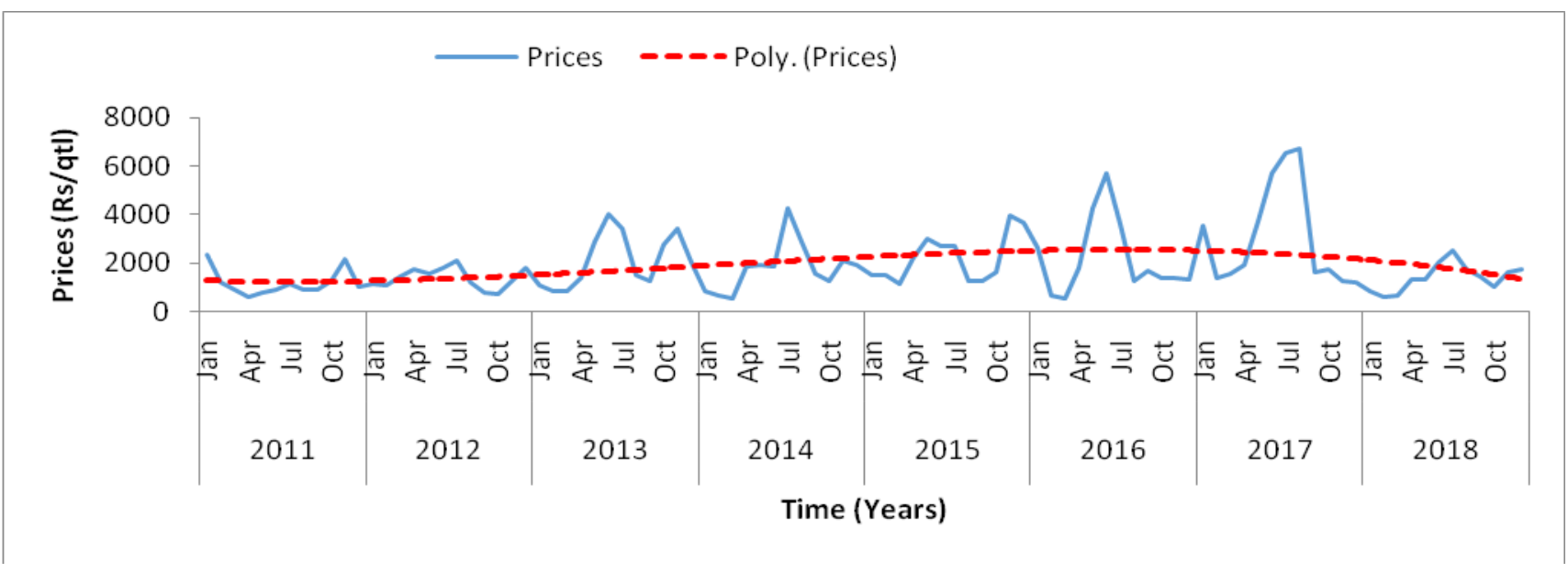


Figure.5 Secular trend analysis of monthly prices of tomato in Paravai market

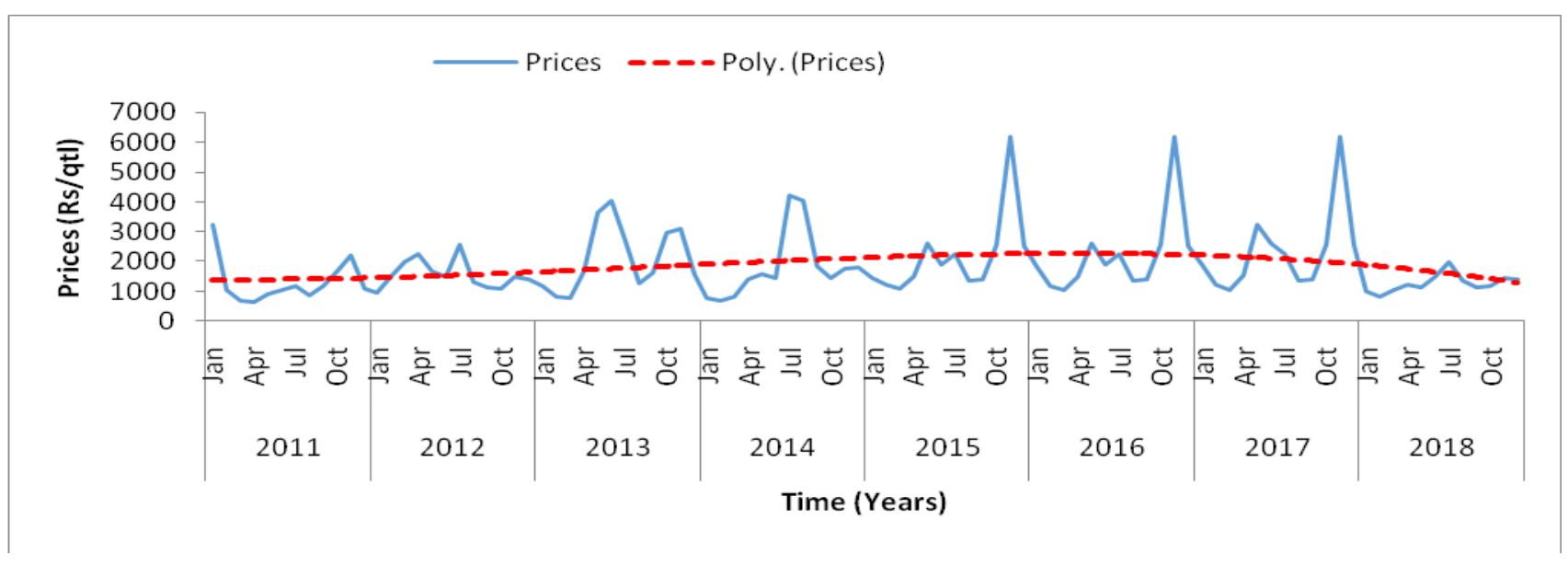

Figure.6 Secular trend analysis of monthly prices of tomato in Coimbatore market

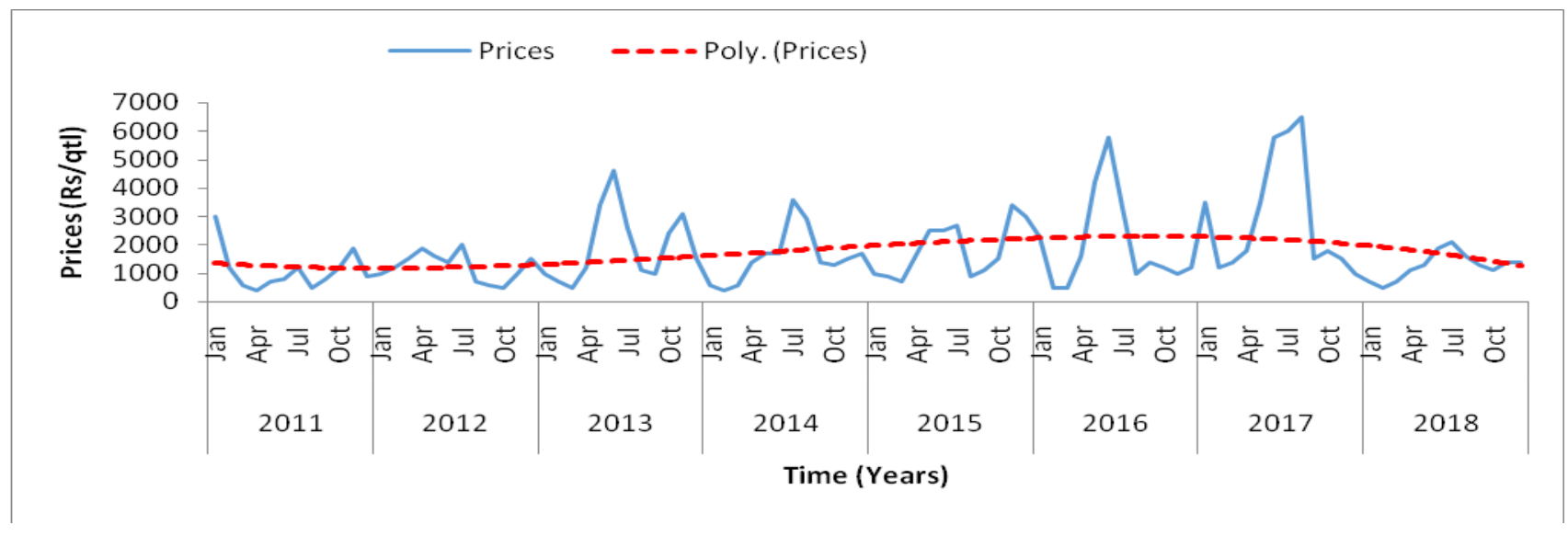

Figure 7: Estimated seasonal indices for arrivals of tomato in selected markets

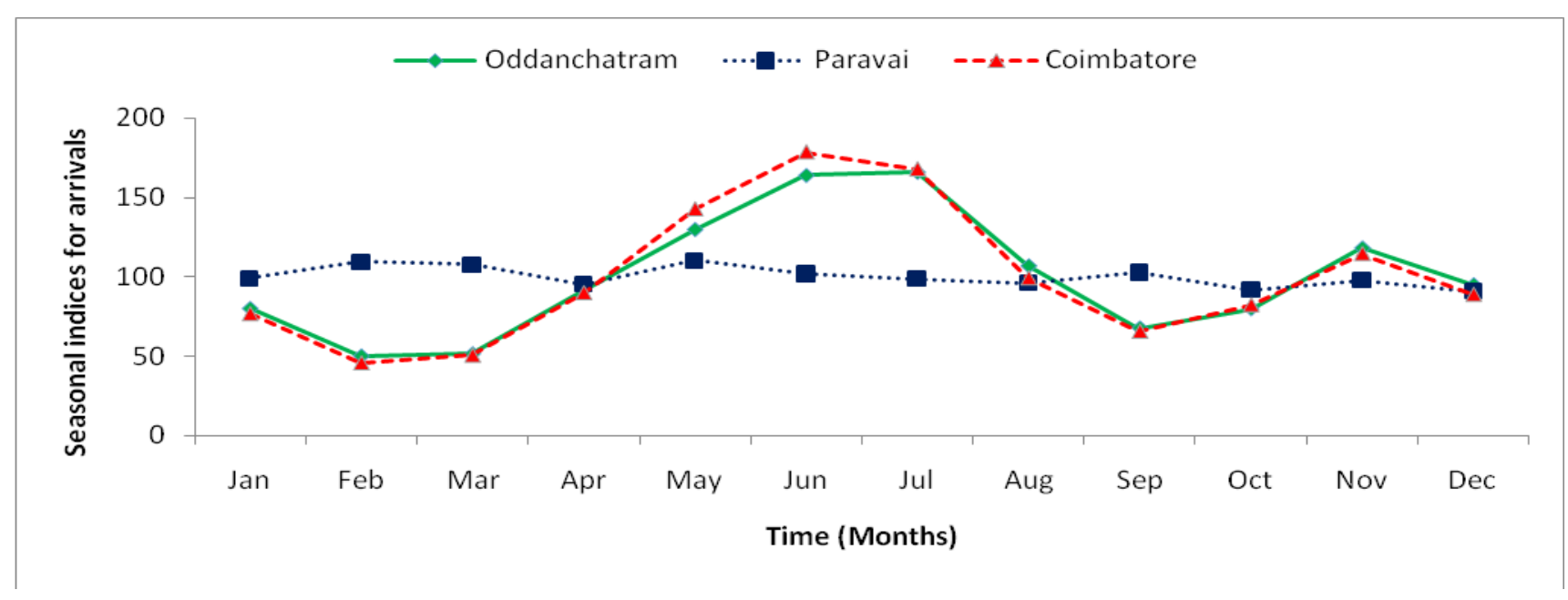


Figure.8 Estimated seasonal indices for prices of tomato in selected markets

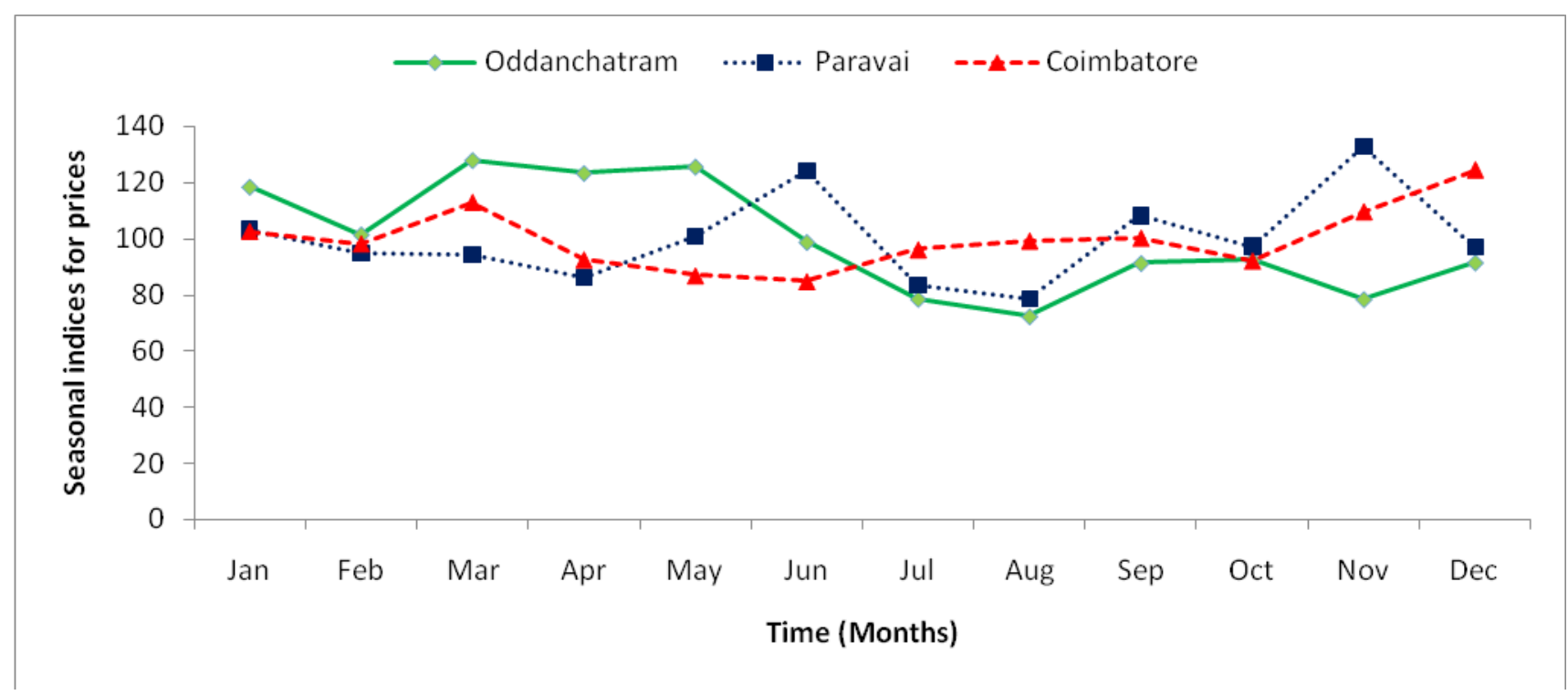

It could be perceived from the Table 3 that in Oddanchatram market, arrivals were loftier in the month of March and lesser in the month of August whereas prices reached its peak in the month of July and lowest observed during the month of February; In Paravai market, the maximum arrivals were identified in the month of November and minimum in the month of August while highest prices were observed in the month of November and lean in the month of February. In Coimbatore vegetable market, the highest arrivals were noticed in the month of December and lowest were observed in June whereas peak prices were observed in the month of June and lean prices were noticed in the month of February.

Two way ANOVA was employed on the results of seasonal components, which discloses that there is significant difference between months and there is no significant difference among years pertaining to arrivals and prices of tomato in all markets except the tomato arrivals in Coimbatore vegetable market. This depicts that presence of seasonality within a year and seasonal pattern did not change over years. In Coimbatore wholesale market, the seasonality pattern did not change within a year as well as over the years. The estimated seasonal Indices for arrivals and prices of tomato in selected markets are given in Figures 7 and 8 respectively.

\section{Correlation coefficient}

It can be observed from Table 4 that there was a negatively significant correlation between arrivals and prices in Coimbatore vegetable market at 5 percent level of significance and negative non significant correlation in Oddanchatram market. Positive significant correlation between arrivals and prices of tomato in Paravai market at 1 percent level of significance infers that both arrivals and prices were moving in same direction but this is against the law.

It is concluded, over the long term, the arrivals of tomato decreases in Oddanchatram and Paravai markets but it an increase in Coimbatore vegetable market and there was no proper trend with respect to prices in all three markets. Tomatoes are usually sown in Rabi season and crop duration is 100-135 days. The harvesting will be held in the 
months of February and March. This was correlated with our results that prices of tomato were always low in the month February and March in all three markets because of crop glut.

\section{References}

Baby Dey, Chhabi and Nirmal De. 2014. Variation in Market Dynamics of Fresh Tomato Crop in Some Selected Capital Market of the Indo-Gangetic Plain Region. Agriculture for Sustainable Development. 2(2): 175-179.

Bera, B., Dutta Jayanta and Nandi, A. 2017. A Study on the Variability in Market Arrivals and Prices of Potato in some selected Markets of West Bengal. International Journal of Agriculture Sciences. 9 (40):4621-4625.
Kumuda Keerthi, P. and Mohan Naidu, G. 2013. Seasonality in market arrivals and prices of tomato in Madanapalli market of chittoor district. The Andhra Agric. Journal. 60(1): 152-156.

Mhatre, S., Bhosale, S. and Diwate Sharad. 2018. Prices behaviour of brinjal in South Region of Gujarat. Indian Journal of Agricultural Marketing. 32(1): 70-77.

Mohan Naidu, G and Ravindra Reddy, B. 2013. Arrivals and prices of onion in Kurnool market of Andhra Pradesh. BIOINFOLET. 10(4B): 1302.

Preethi, V.P., Thomas, J., Anil, K and Sachin, C.P. 2019. Price behaviour of coconut in major Markets of Kerala: A time series analysis. International Journal of Chemical Studies. 7(1): 148-154.

\section{How to cite this article:}

Tamilselvi, C., G. Mohan Naidu, B. Ramana Murthy and Rajeswari, S. 2020. Behavioural Study of Market Arrivals and Prices of Tomato in Major Markets of Tamil Nadu - A Time Series Analysis. Int.J.Curr.Microbiol.App.Sci. 9(07): 3495-3413.

doi: https://doi.org/10.20546/ijcmas.2020.907.399 